\title{
Barriers and facilitators for shared decision making in older patients with multiple chronic conditions: a systematic review
}

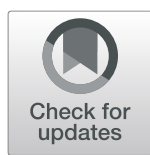

Ruth E. Pel-Littel ${ }^{1,2^{*}}$ (D, Marjolein Snaterse ${ }^{3}$, Nelly Marela Teppich', Bianca M. Buurman²,3,

Faridi S. van Etten-Jamaludin ${ }^{4}$, Julia C. M. van Weert ${ }^{5}$, Mirella M. Minkman ${ }^{1,6}$ and Wilma J. M. Scholte op Reimer ${ }^{3,7}$

\begin{abstract}
Background: The aim of this study was to describe barriers and facilitators for shared decision making (SDM) as experienced by older patients with multiple chronic conditions (MCCs), informal caregivers and health professionals.

Methods: A structured literature search was conducted with 5 databases. Two reviewers independently assessed studies for eligibility and performed a quality assessment. The results from the included studies were summarized using a predefined taxonomy.

Results: Our search yielded 3838 articles. Twenty-eight studies, listing 149 perceived barriers and 67 perceived facilitators for SDM, were included. Due to poor health and cognitive and/or physical impairments, older patients with MCCs participate less in SDM. Poor interpersonal skills of health professionals are perceived as hampering SDM, as do organizational barriers, such as pressure for time and high turnover of patients. However, among older patients with MCCS, SDM could be facilitated when patients share information about personal values, priorities and preferences, as well as information about quality of life and functional status. Informal caregivers may facilitate SDM by assisting patients with decision support, although informal caregivers can also complicate the SDM process, for example, when they have different views on treatment or the patient's capability to be involved. Coordination of care when multiple health professionals are involved is perceived as important.

Conclusions: Although poor health is perceived as a barrier to participate in SDM, the personal experience of living with MCCs is considered valuable input in SDM. An explicit invitation to participate in SDM is important to older adults. Health professionals need a supporting organizational context and good communication skills to devise an individualized approach for patient care.
\end{abstract}

Keywords: Participation, Communication, Preferences, Personal experience, Informal caregivers

\footnotetext{
*Correspondence: r.pel@vilans.nl

${ }^{1}$ Vilans, Centre of Expertise for Long-term Care, PO Box 8228, Utrecht, RE

3503, the Netherlands

${ }^{2}$ Department of Internal Medicine, Section of Geriatric Medicine, Amsterdam

University Medical Center, University of Amsterdam, Amsterdam, the

Netherlands

Full list of author information is available at the end of the article
}

(C) The Author(s). 2021 Open Access This article is licensed under a Creative Commons Attribution 4.0 International License, which permits use, sharing, adaptation, distribution and reproduction in any medium or format, as long as you give appropriate credit to the original author(s) and the source, provide a link to the Creative Commons licence, and indicate if changes were made. The images or other third party material in this article are included in the article's Creative Commons licence, unless indicated otherwise in a credit line to the material. If material is not included in the article's Creative Commons licence and your intended use is not permitted by statutory regulation or exceeds the permitted use, you will need to obtain permission directly from the copyright holder. To view a copy of this licence, visit http://creativecommons.org/licenses/by/4.0/ The Creative Commons Public Domain Dedication waiver (http://creativecommons.org/publicdomain/zero/1.0/) applies to the data made available in this article, unless otherwise stated in a credit line to the data. 


\section{Background}

There is much agreement that the prevalence of multiple chronic conditions (MCCs) has many negative consequences for older adults, such as functional impairment, a high treatment burden, a decline in health-related quality of life, increased use of health care and a higher risk of mortality [1-9]. Therefore, for many older adults with MCCs, maintaining (functional) independence, reducing symptom burden and acquiring emotional health and safety might be more important health outcomes than disease-specific outcomes [10]. The best treatment for the disease might not be the same as the best treatment for the patient as a whole. However, this requires another style of health care communication: instead of focusing on the treatment of each individual condition, the conversation should start with exploring an older adult's priorities regarding preferred health outcomes, thus guiding the discussion of options and decisions about treatment or care. Since both the personal preferences of the older adult and the professional experience of the health professional are needed, this process is called 'shared decision making'.

Shared decision making (SDM) facilitates the discussion between health professionals and older patients with multiple chronic conditions (MCCs) when decisions have to be made about the desired care and treatment. Elwyn (2017) describes SDM as "a process in which decisions are made in a collaborative way, where trustworthy information is provided in accessible formats about a set of options, typically in situations where the concerns, personal circumstances, and contexts of patients and their families play a major role in decisions [11]. The outcomes of SDM mainly report on cognitiveaffective outcomes of SDM, such as knowledge and decisional conflict, and the evidence points towards positive effects of SDM in this perspective [12-14]. In particular the many studies about the use of patient decision aids provide evidence about better informed patients [12, 15]. There are fewer studies about behavioral outcomes such as compliance to treatment or adoption of health behaviors and about health outcomes such as quality of life [14]. Also the evidence in those studies directs less clearly to positive effects of SDM [16, 17].

SDM is not yet common practice; it is estimated that in only $10 \%$ of the situations in which health decisions have to be made, SDM is used [18]. Both health professionals and patients experience barriers in making shared decisions. Most reviews focus on SDM in a general population [19-21]. One review reveals barriers and facilitators of SDM in the daily life of people with dementia [22]. However, we expect that when facing decisions, older patients with MCCs and their informal caregivers may encounter additional barriers and facilitators, which should be identified to support the implementation of SDM [12, 23]. For example, characteristics such as anxiety, low health literacy and frailty are highly prevalent among older adults with MCCs and may influence the SDM process [24-28]. Anxiety is highly prevalent among older adults and associated with MCCs [24, 25]. Anxiety in SDM may leave the patient wanting to surrender decision making to the clinician [29]. Low HL is especially prevalent among older adults, with rates of low health literacy ranging from 30 to $68 \%$ $[27,30,31]$. The prevalence of low HL increases when there are MCCs [27]. Low HL among older adults is associated with poor shared decision making ability [27]. Older adults with MCCs who lack the ability to understand and communicate information may have trouble participating in parts of the SDM process, such as interpretation of test results and understanding the risks and benefits of procedures, leading to uncertainty and decisional conflict $[27,28]$. It is estimated that approximately $20-30 \%$ of adults over 75 years are frail [32]. For adults who are frail, balancing benefits and harms of a treatment is important, since resilience capacity is often low. Furthermore, the presence of an informal caregiver, such as a family member or friend, at a medical consultation is common among older adults with MCCs. For example, in our observational study we found that in $63 \%$ of the geriatric consultations older adults were accompanied by informal caregivers [33]. Informal caregivers are often involved in discussing the patients health situation and participate in decision making [34]. Their role becomes more substantial when older patients are less able to participate in the consultation, for example in cases of cognitive decline [35-37]. Therefore, SDM with older adults with MCCs often has a triadic character, in which older patients with MCCs, their informal caregivers and health professionals participate.

In a previous review about patient-reported barriers and facilitators to SDM a taxonomy of barriers and facilitators to SDM was developed [19]. In this taxonomy (see Supplementary Table S2) barriers and facilitators were coded into the following categories: predisposing factors (patient and decision characteristics), interactional context factors (social factors regarding the relation between patients and health professionals), preparation for the SDM encounter (perceived need for preparation by patients and expectations about involvement) and preparation for the SDM process (providing information about options, decision support and terminology used). To gain more insight into the implementation of SDM, we enriched this taxonomy with organizational factors (health care organizations), social factors (health care settings, interdisciplinary team) and policy factors (health care system, health government) as reported by Grol et al. [38]. To explain the taxonomy, we developed Fig. 1, which visualizes the adapted taxonomy. From all three perspectives (patient, informal 


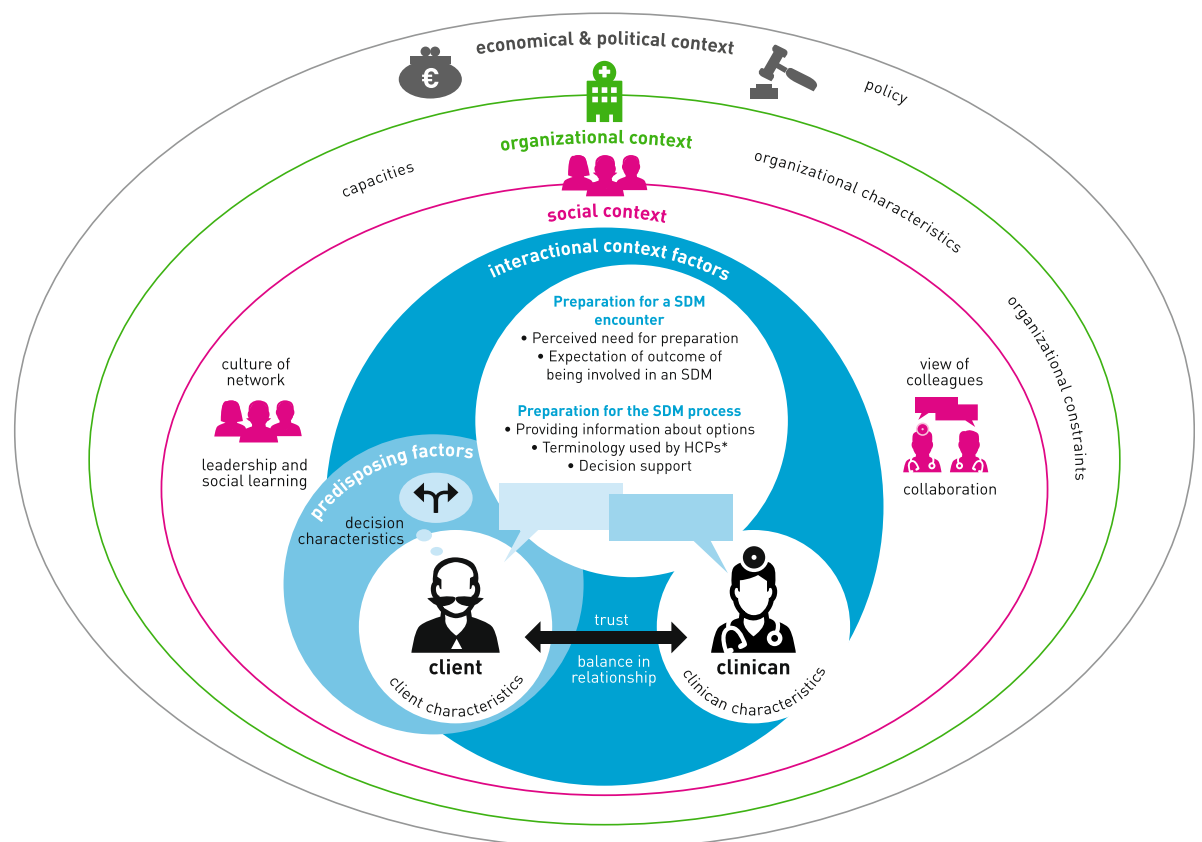

Fig. 1 Adapted taxonomy for barriers of and facilitators to shared decision making

caregiver and health care professional), barriers and facilitators could be reported for all types of factors.

The aim of this study is to conduct a systematic review to identify barriers and facilitators that older patients with MCCs, their informal caregivers and health professionals experience in SDM.

\section{Methods}

This systematic review followed the Preferred Reporting Items for Systematic Reviews and Meta-analysis (PRIS MA) statement [39].

\section{Search strategy}

We searched five electronic databases (Medline, EMBASE, PsycINFO, Cinahl, and Cochrane Central Register of Controlled Trials (Central)). Because the concept of SDM was not widely spread until the early 1990s, our search covers the period from 1980 to January 1, 2019. Based on a list of 20 key articles in the field of barriers and facilitators to SDM, the clinical librarian developed a search strategy (Supplementary Table S1). We used both keywords and MeSH terms for 'shared decision making', 'older patients', 'multiple chronic conditions', 'barriers' and 'facilitators'.

\section{Eligibility criteria}

A study was eligible for inclusion if 1) it was an original collection of data, 2) the design targeted older people (mean age $\geq 65$ years) with MCCs $(\geq 2$ chronic conditions), 3) the results reported perceived barriers and/or facilitators for SDM, and 4) the study focused on either the perspective of patients and/or that of informal caregivers, health professionals or both. Health professionals were defined as medical staff, nurses and other professions allied to medicine, e.g. clinical psychologists, dieticians, physiotherapists. Conference/poster abstracts and articles that could not be retrieved were excluded.

\section{Study selection}

First, titles and abstracts, and second, full-text versions of potentially relevant articles were screened independently by two authors (RP, NT) on the basis of the eligibility criteria. Disagreements were resolved through discussion with a third reviewer (MS).

\section{Data extraction and quality assessment}

Information about the characteristics of the studies (type, setting) and perceived barriers and facilitators to SDM were extracted independently by two reviewers (RP, NT) using a data extraction sheet. Data synthesis was achieved using deductive content analysis. The reviewers identified each unit of text (a paragraph or sentence depicting one idea) relevant to the main outcomes (barriers or facilitators to SDM). Each unit of text was subsequently coded according to the taxonomy of barriers and facilitators to SDM. Two researchers (RP, NT) independently coded all retrieved units of text, and any discrepancies between the codes were resolved through discussions.

Similar to other reviews about facilitators and barriers for SDM, the quality of the included studies was 
assessed using the Standard Quality Assessment Criteria for Evaluating Primary Research Papers from a Variety of Fields (SQAC) [19, 21, 40]. The quality scores of the SQAC were used to define a minimum threshold for the inclusion of studies. Following the SQAC manual, the cut-point for exclusion was set at $<.55$ (range $0-1$ ). All studies were independently assessed by two researchers (RP, NT), and disagreements were resolved through discussion with a third reviewer (MS).

\section{Results}

\section{Study selection}

The database searches generated 3838 unique abstracts. After screening titles and abstracts, 183 full texts were reviewed, of which 28 studies met the inclusion criteria (Fig. 2).

\section{Study characteristics}

The included studies (Table 1) comprised 2990 older adults, 337 informal caregivers (IC) and 527 health professionals (HCPs). The studies originated from the U.S.A. $(n=13)$, Canada $(n=4)$, Sweden $(n=4)$, Norway $(n=2)$, the Netherlands $(n=2)$, Australia $(n=1)$, Germany $(n=1)$ and the U.K. $(n=1)$. Nineteen studies used a qualitative design [41, 42, 44, 46, 47, 49-51, 54, $55,57,59-63,65,66,68]$, five studies used a quantitative design $[43,45,48,58,64]$ and four studies used a mixed-method design $[52,53,56,67]$. Neither the quantitative nor the mixed-methods studies carried statistical analysis out regarding the barriers and facilitators, they all reported in a qualitative way on the perceived barriers and facilitators. The 28 studies reported perceived barriers and facilitators from different stakeholder perspectives: nine studies (32\%) reported on the patient perspective [41-49], three studies (11\%) focused on the informal caregiver perspective [57-59], eight studies (29\%) reported on the health professional perspective, and 7 studies (25\%) reported more than one perspective [50-56]. Decisions were about medical treatment [43, $45,47,48,50,60,61,64,67]$, medication [44, 65], goals of care [50, 53, 62, 63, 66], daily life and lifestyle [41, 50, $58,64]$, hospital admission or discharge $[46,57,68]$ and ethical or end-of-life dilemmas [42, 49].

Ten studies were based in a hospital setting [46-48, $50,56,57,60,63,65,68]$, six in a primary care setting $[43,44,51,55,61,67]$, four in a community care setting $[45,49,58,59,69]$, one in a long-term care setting [41], one in a hospice [42], one in a post-acute residential care setting [64], one in a rehabilitation setting [53], and one in a geropsychiatric inpatient unit [66]. Three studies were based in a combined setting, e.g., hospital and primary care [52, 54, 62]. The study patients' age for each study is depicted in Table 1. In all studies, patients had $\geq 2$ diagnoses, although in one study, a subgroup of patients had $\leq 2$ diagnoses [45].

\section{Quality assessment}

Supplementary Table S3 shows the quality assessment scores of the included studies. All qualitative studies scored $>.55$ and thus met the quality standard. However, three qualitative studies $[49,63,66]$ were case studies and could not be assessed within the SQAC format. All the quantitative studies scored $>.77$. The mixedmethod studies had a summarized score $>0.80$ (see Supplementary Table S3).

\section{Barriers and facilitators of SDM for older patients with MCCs}

A comprehensive overview of all barriers and facilitators found is presented in Table 2. From the twenty-eight included studies, we found 149 perceived barriers and 67 perceived facilitators for SDM in older patients with MCCs. Most barriers were found in the following categories: predisposing factors $(n=51,34 \%)$, interactional context factors $(n=32,21 \%)$ and organizational context factors $(n=22,15 \%)$. Most facilitators were found in the following categories: interactional context factors $(n=$ $23,34 \%)$ and preparation for the SDM process $(n=19$, $28 \%$ ). In Table 2 is also depicted how many studies reported about a specific barrier or facilitator, to provide insight into how often a factor was reported. In the next section the most frequently mentioned barriers and facilitators are described and explained from which perspective the barriers and facilitators were reported: patient perspective (PP), informal caregiver perspective (IP) or health professional perspective (HP).

\section{Predisposing factors \\ Perceived barriers}

When one is very ill, this affects one's ability to understand information (HP/PP) [46-48] and to participate in decision making (PP) [42, 48]. Patients suffering from MCCs are less likely to participate in SDM and worry about the burden of a treatment regime (PP/IP/HP) [45, 54, 59, 61]. Cognitive and physical impairments were considered barriers for SDM by patients, informal caregivers and health professionals. Cognitive impairment leads to difficulties in understanding information (PP/IP/ HP) $[47,48,58,60,63]$, not being able to express preferences (HP) [60], and not wanting (HP) [64] or not being able (PP) [47] to partake in decision making. Physical impairments can influence compliance (HP) [61], whereas severe illness (PP) [42] can keep older patients with MCCs from being able to partake in decision making. Health professionals often struggle with the uncertainties of applying disease-specific guidelines to older patients with MCCs (PP/IP/HP) [54, 61, 65]. For 

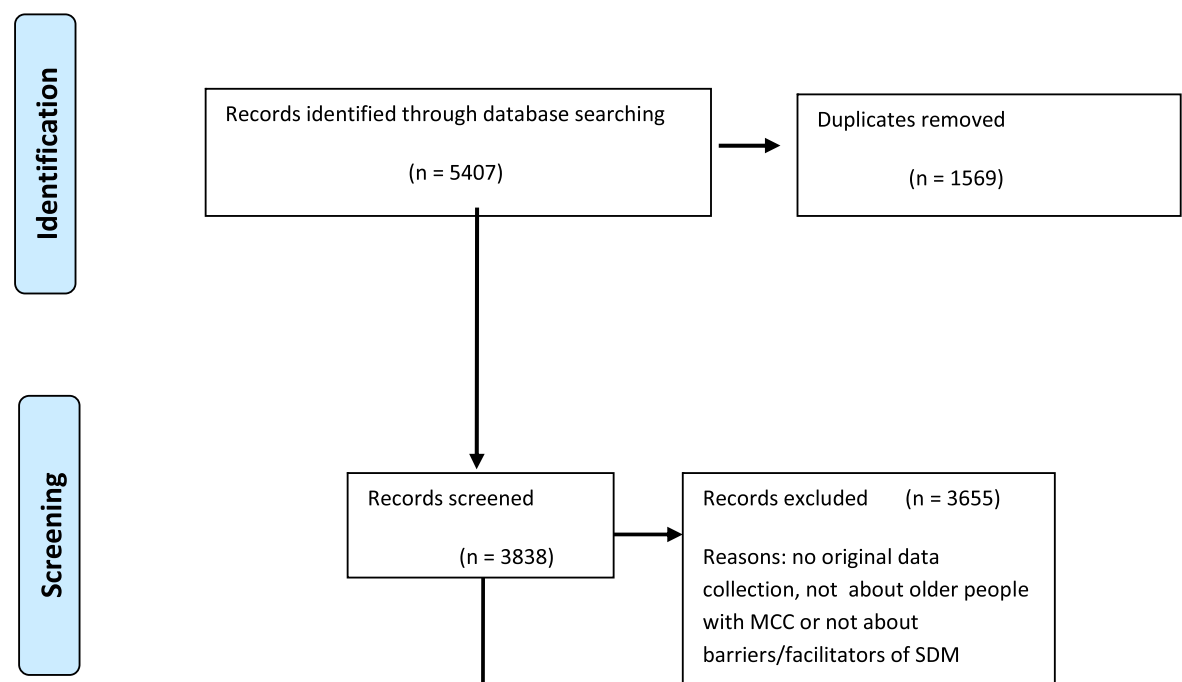

Records excluded $\quad(n=3655)$

Reasons: no original data collection, not about older people with MCC or not about barriers/facilitators of SDM

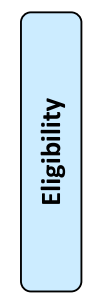

Full-text articles excluded, with reasons $(n=155)$

Full-text articles assessed for eligibility $(n=183)$

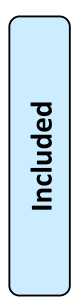

No original collection of data (31)

Not about older people with MCC (59)

Not about SDM (28)

Not about barriers/facilitators for SDM (28)

Conference/poster abstract (7)

Could not be retrieved (2)

Studies included in the review

$(n=28)$

Fig. 2 PRISMA flow diagram of literature review process for studies on barriers of and facilitators to shared decision making in older patients with multiple chronic conditions

information about the exact numbers of articles reporting barriers, we refer to Table 2.

\section{Perceived facilitators}

Previous experience in dealing with conditions and decision making acts as a facilitator to SDM (PP) [41, 44, 46]. Additionally, having personal values, such as religion, views on survival and suffering, and self-sufficiency facilitates the SDM process (PP/IP) [50]. For information about the exact numbers of articles reporting facilitators, we refer to Table 2.

\section{Interactional context factors}

Perceived barriers

Both patients and health professionals reported poor communication techniques, poor language choice and lack of empathy as barriers for shared decision making $(\mathrm{PP} / \mathrm{HP})$ [44, 47, 63]. Older patients had little confidence that they could have a meaningful contribution to the shared decision-making process, or they felt that a lack of (medical) knowledge made them unable to participate (PP) $[41,44]$. On the other hand, some patients reported feeling that health professionals undervalue the expertise of patients $(\mathrm{P})$ [55]. Informal caregivers expressed dependency; they felt they were at the mercy of the individual health care personnel and that, in the end, the final decisions were made by the health professionals (IP/PP) $[46,57]$. Health professionals acknowledged that most of the time patients and informal caregivers are not seen as part of the health care team (IP/PP/HP) [46, $47,55,57]$. 
Table 1 Characteristics of the included studies

\begin{tabular}{|c|c|c|c|c|c|c|c|c|}
\hline $\begin{array}{l}\text { First } \\
\text { author }\end{array}$ & Setting & Country & $\begin{array}{l}\text { Design } \\
\text { study }\end{array}$ & $\begin{array}{l}\text { Reporting } \\
\text { focus }: \text { Barriers } \\
\text { (B) and/or } \\
\text { Facilitators (F) }\end{array}$ & Perspective $^{\mathbf{b}}$ & Participants (n) & $\%$ Female & $\begin{array}{l}\text { Mean age of } \\
\text { patients (years) } \\
\text { (if not available: } \\
\text { age range) }\end{array}$ \\
\hline $\begin{array}{l}\text { Funk [41], } \\
2004\end{array}$ & LTC facilities & Canada & Qualitative & B\&F & Patients & 100 patients & 82 & 85 \\
\hline $\begin{array}{l}\text { Gauthier } \\
\text { [42], } 2005\end{array}$ & hospital & U.S.A. & Qualitative & $B \& F$ & Patients & 13 patients & 62 & 72 \\
\hline $\begin{array}{l}\text { Naik [43], } \\
2011\end{array}$ & primary care & U.S.A. & Quantitative & B & Patients & 100 patients & 100 & 71 \\
\hline $\begin{array}{l}\text { Belcher } \\
\text { [44], } 2006\end{array}$ & primary care & U.S.A. & Qualitative & $B \& F$ & Patients & 51 patients, & 63 & 77 \\
\hline $\begin{array}{l}\text { Chi [45], } \\
2017\end{array}$ & $\begin{array}{l}\text { community } \\
\text { care }\end{array}$ & U.S.A. & Quantitative & B & Patients & 2017 patients & 57 & range $65>85$ \\
\hline $\begin{array}{l}\text { Dyrstad } \\
\text { [46], } 2015\end{array}$ & hospital & Norway & Qualitative & $B \& F$ & Patients & 41 patients & 46 & 86 \\
\hline $\begin{array}{l}\text { Ekdahl } \\
\text { [47], } 2010\end{array}$ & hospital & Sweden & Qualitative & $B \& F$ & Patients & 15 patients & 67 & 84 \\
\hline $\begin{array}{l}\text { Ekdahl } \\
\text { [48], } 2011\end{array}$ & hospital & Sweden & Quantitative & B & Patients & 156 patients & 49 & 83.1 \\
\hline $\begin{array}{l}\text { Erickson } \\
\text { [49], } 1989\end{array}$ & $\begin{array}{l}\text { community } \\
\text { care }\end{array}$ & U.S.A. & $\begin{array}{l}\text { Qualitative } \\
\text { (case study) }\end{array}$ & B & Patients & 1 patient & 100 & 75 \\
\hline $\begin{array}{l}\text { Petrillo } \\
\text { [50], } 2018\end{array}$ & hospital & U.S.A. & Qualitative & $\mathrm{F}$ & $\begin{array}{l}\text { Patients and } \\
\text { informal } \\
\text { caregivers }\end{array}$ & $\begin{array}{l}38 \text { patients } \\
31 \text { informal } \\
\text { caregivers }\end{array}$ & $\begin{array}{l}48 \text { (total } \\
\text { group) }\end{array}$ & 78 \\
\hline $\begin{array}{l}\text { Riffin [51], } \\
2018\end{array}$ & primary care & U.S.A. & Qualitative & B & $\begin{array}{l}\text { Patients and } \\
\text { informal } \\
\text { caregivers }\end{array}$ & $\begin{array}{l}20 \text { patients } \\
20 \text { informal } \\
\text { caregivers }\end{array}$ & $\begin{array}{l}61 \\
65\end{array}$ & 82 \\
\hline $\begin{array}{l}\text { Kiselev } \\
\text { [52], } 2017\end{array}$ & $\begin{array}{l}\text { hospital \& } \\
\text { community } \\
\text { care }\end{array}$ & Germany & $\begin{array}{l}\text { Mixed } \\
\text { methods }\end{array}$ & $B \& F$ & $\begin{array}{l}\text { Patients and } \\
\text { health } \\
\text { professionals }\end{array}$ & $\begin{array}{l}283 \text { patients } \\
14 \text { professionals } \\
\text { (clinicians, nurses, } \\
\text { therapists, } \\
\text { psychologist, social } \\
\text { worker) }\end{array}$ & $\begin{array}{l}66 \\
\text { unk. }\end{array}$ & 74.4 \\
\hline $\begin{array}{l}\text { Rose [53], } \\
2018\end{array}$ & rehabilitation & U.K. & $\begin{array}{l}\text { Mixed } \\
\text { methods }\end{array}$ & B & $\begin{array}{l}\text { Patients and } \\
\text { health } \\
\text { professionals }\end{array}$ & $\begin{array}{l}40 \text { patients } \\
24 \text { professionals } \\
\text { (rehabilitation staff) }\end{array}$ & $\begin{array}{l}23 \\
\text { unk. }\end{array}$ & 83 \\
\hline $\begin{array}{l}\text { Ferris [54], } \\
2018\end{array}$ & $\begin{array}{l}\text { health care } \\
\text { users and } \\
\text { providers }\end{array}$ & U.S.A. & Qualitative & $B \& F$ & $\begin{array}{l}\text { Patients, } \\
\text { informal } \\
\text { caregivers and } \\
\text { health } \\
\text { professionals }\end{array}$ & $\begin{array}{l}6 \text { patients or informal } \\
\text { caregivers } \\
30 \text { clinicians, health } \\
\text { systems, and payers }\end{array}$ & unk. & unk. \\
\hline $\begin{array}{l}\text { Doekhie } \\
\text { [55] }\end{array}$ & primary care & $\begin{array}{l}\text { The } \\
\text { Netherlands }\end{array}$ & Qualitative & B & $\begin{array}{l}\text { Patients, } \\
\text { informal } \\
\text { caregivers and } \\
\text { health } \\
\text { professionals }\end{array}$ & $\begin{array}{l}19 \text { patients } \\
10 \text { informal } \\
\text { caregivers } \\
38 \text { professionals } \\
\text { (clinicians, nurses, } \\
\text { paramedics) }\end{array}$ & $\begin{array}{l}79 \\
40 \\
\text { unk. }\end{array}$ & 81.6 \\
\hline $\begin{array}{l}\text { Puts [56], } \\
2017\end{array}$ & hospital & Canada & $\begin{array}{l}\text { Mixed } \\
\text { methods }\end{array}$ & B & $\begin{array}{l}\text { Patients, } \\
\text { informal } \\
\text { caregivers and } \\
\text { health } \\
\text { professionals }\end{array}$ & $\begin{array}{l}29 \text { patients } \\
24 \text { informal } \\
\text { caregivers } \\
28 \text { professionals } \\
\text { (oncologists and } \\
\text { family physicians) }\end{array}$ & 24 resp. 36 & $\begin{array}{l}\text { patients divided } \\
\text { in } 2 \text { age groups: } \\
63-79 \&>80\end{array}$ \\
\hline $\begin{array}{l}\text { Bragstad } \\
{[57], 2014}\end{array}$ & hospital & U.S.A. & Qualitative & B & $\begin{array}{l}\text { Informal } \\
\text { caregivers }\end{array}$ & $\begin{array}{l}19 \text { informal } \\
\text { caregivers }\end{array}$ & 68 & n.a. ${ }^{d}$ \\
\hline $\begin{array}{l}\text { Menne } \\
\text { [58], } 2008\end{array}$ & $\begin{array}{l}\text { community } \\
\text { care }\end{array}$ & U.S.A. & Quantitative & $B \& F$ & $\begin{array}{l}\text { Informal } \\
\text { caregivers }\end{array}$ & $\begin{array}{l}215 \text { informal } \\
\text { caregivers }\end{array}$ & 50 & n.a. \\
\hline Peacock & community & Canada & Qualitative & B & Informal & 18 informal & 44 & n.a. \\
\hline
\end{tabular}


Table 1 Characteristics of the included studies (Continued)

\begin{tabular}{|c|c|c|c|c|c|c|c|c|}
\hline $\begin{array}{l}\text { First } \\
\text { author }\end{array}$ & Setting & Country & $\begin{array}{l}\text { Design } \\
\text { study }\end{array}$ & $\begin{array}{l}\text { Reporting } \\
\text { focus }{ }^{a} \text { : Barriers } \\
\text { (B) and/or } \\
\text { Facilitators (F) }\end{array}$ & Perspective $^{\mathbf{b}}$ & Participants (n) & $\%$ Female & $\begin{array}{l}\text { Mean age of } \\
\text { patients (years) } \\
\text { (if not available: } \\
\text { age range) }\end{array}$ \\
\hline [59], 2017 & care & & & & caregivers & caregivers & & \\
\hline $\begin{array}{l}\text { Ekdahl } \\
{[60], 2012}\end{array}$ & hospital & Sweden & Qualitative & $B \& F$ & $\begin{array}{l}\text { Health } \\
\text { professionals }\end{array}$ & 29 physicians & 34 & n.a. \\
\hline $\begin{array}{l}\text { Fried [61], } \\
2011\end{array}$ & primary care & U.S.A. & Qualitative & B & $\begin{array}{l}\text { Health } \\
\text { professionals }\end{array}$ & 40 physicians & & n.a. \\
\hline $\begin{array}{l}\text { Blaum } \\
\text { [62], } 2018\end{array}$ & $\begin{array}{l}\text { primary care \& } \\
\text { hospital }\end{array}$ & U.S.A. & Qualitative & B & $\begin{array}{l}\text { Health } \\
\text { professionals }\end{array}$ & $\begin{array}{l}9 \text { general } \\
\text { practitioners, } 5 \\
\text { cardiologists }\end{array}$ & & n.a. \\
\hline $\begin{array}{l}\text { Gopalraj } \\
\text { [63], } 2012\end{array}$ & hospital & U.S.A. & $\begin{array}{l}\text { Qualitative } \\
\text { (case study) }\end{array}$ & $B \& F$ & $\begin{array}{l}\text { Health } \\
\text { professionals }\end{array}$ & 1 patient & 100 & 94 \\
\hline $\begin{array}{l}\text { Milte [64], } \\
2015\end{array}$ & $\begin{array}{l}\text { geropsychiatry } \\
\text { inpatient unit }\end{array}$ & Australia & Quantitative & B & $\begin{array}{l}\text { Health } \\
\text { professionals }\end{array}$ & 2 geriatricians & 59 & n.a. \\
\hline $\begin{array}{l}\text { Schuling } \\
\text { [65], } 2012\end{array}$ & hospital & $\begin{array}{l}\text { The } \\
\text { Netherlands }\end{array}$ & Qualitative & B & $\begin{array}{l}\text { Health } \\
\text { professionals }\end{array}$ & 13 physicians & 15 & n.a. \\
\hline $\begin{array}{l}\text { Molinari } \\
\text { [66], } 2016\end{array}$ & $\begin{array}{l}\text { geropsychiatry } \\
\text { inpatient unit }\end{array}$ & U.S.A. & $\begin{array}{l}\text { Qualitative } \\
\text { (case study) }\end{array}$ & $\mathrm{F}$ & $\begin{array}{l}\text { Health } \\
\text { professionals }\end{array}$ & 1 patient & 0 & 'late 60s' \\
\hline $\begin{array}{l}\text { Légaré } \\
\text { [67], } 2013\end{array}$ & primary care & Canada & $\begin{array}{l}\text { Mixed } \\
\text { methods }\end{array}$ & $B \& F$ & $\begin{array}{l}\text { Health } \\
\text { professionals }\end{array}$ & $\begin{array}{l}\text { Participants: } \\
\text { a) } 276 \text { home care } \\
\text { providers } \\
\text { b) } 7 \text { members health } \\
\text { care team } \\
\text { c) } 8 \text { managers }\end{array}$ & $\begin{array}{l}\text { Participants: } \\
\text { a) } 82 \\
\text { b) } 100 \\
\text { c) } 50\end{array}$ & n.a. \\
\hline $\begin{array}{l}\text { Lindhardt } \\
\text { [68], } 2008\end{array}$ & hospital & Sweden & Qualitative & $B \& F$ & $\begin{array}{l}\text { Health } \\
\text { professionals }\end{array}$ & 8 nurses & 100 & n.a. \\
\hline
\end{tabular}

“'Reporting focus' refers to whether the study reports about perceived barriers to and/or facilitators of SDM

${ }^{b}$ 'Perspective' refers to either the perspective of patients or informal caregivers or health professional from which the perceived barriers or facilitators are reported. Some studies describe perceived barriers or facilitators from more than one perspective

cunk unknown

${ }^{d}$.a not applicable

\section{Perceived facilitators}

Health professionals report that clinicians who assessed a patient's ability to understand information and to describe his or her symptoms, thoughts and feelings, particularly for patients with cognitive decline, facilitated SDM (HP) [60, 63]. Patients reported that they did feel invited to partake in shared decision making when the doctor stimulated them to describe symptoms and ask questions and inquired what the patient's main worries were (PP/HP) [44, 46, 64]. Additionally, holding the belief that they are the ones with the most knowledge about their own body and particular conditions facilitated active involvement of older patients (PP) [44].

\section{Preparation for an SDM encounter \\ Perceived barriers}

Not all patients want or need to participate in SDM (HP/ PP) $[41,47,60]$. A segment of the older patients preferred a more passive role in SDM (HP/PP) [41, 47, 60]. Health professionals, however, viewed a lack of participation as a barrier to SDM because they feel uncomfortable when they have to guess the patient's preferences (HP/PP) [47, 60]. Different views may complicate SDM, e.g., patients focus on treatment burden versus clinicians concerns about morbidity and mortality (HP) [61, 62].

\section{Perceived facilitators}

Patients feel they have an own responsibility in asking questions, learning about their disease and medications and inquiring on investigations and medical considerations (PP) [44, 47]. Also, patients suggested that motivation, self-confidence, preparing themselves and family support could enable them to participate in SDM (PP/HP) [53].

\section{Preparation for the SDM process Perceived barriers}

When health professionals did not adapt information to the personal needs and capacities of patients or used medical terminology, their behaviours were experienced as a barrier to SDM (PP) [46, 48]. Decision support from informal caregivers can also be a burden to SDM. First, informal caregivers sometimes feel forced responsibility in decision making (IP) [59]. Second, there can be different views between informal caregivers and health professionals, e.g., informal caregivers being 
Table 2 Barriers and facilitators for SDM in older patients with MCCs

\begin{tabular}{|c|c|c|c|}
\hline Factor & & $\begin{array}{l}\text { Barriers (number of studies in which this } \\
\text { factor was identified as a barrier) }\end{array}$ & $\begin{array}{l}\text { Facilitators (number of studies in which } \\
\text { this factor was identified as a facilitator) }\end{array}$ \\
\hline \multirow[t]{2}{*}{$\begin{array}{l}\text { Predisposing } \\
\text { factors }\end{array}$} & Patient characteristics & $\begin{array}{l}\text { Being in poor health: } 13 \\
\text { Cognitive/physical impairments: } 13 \\
\text { Lower level of education: } 5 \\
\text { Age: } 4 \\
\text { Poor articulation: } 4 \\
\text { Difference in personal characteristics: None } \\
\text { Health condition - stigma/discrimination: } 2 \\
\text { Ethnicity: } 1 \\
\text { Long term patient: } 1\end{array}$ & $\begin{array}{l}\text { Prior exposure to illness/decision making } \\
\text { point: } 4 \\
\text { Personal values: } 1 \\
\text { Being in good health: } 1 \\
\text { Long term patient: None }{ }^{a}\end{array}$ \\
\hline & Decision characteristics & $\begin{array}{l}\text { Disease-based decision models (guidelines): } 3 \\
\text { Burden of treatment regimen: } 2 \\
\text { Shock of receiving diagnosis: } 2 \\
\text { Minor decision: } 1 \\
\text { Timing along the illness trajectory: None } \\
\text { Major decision: None } \\
\text { Embarrassing or sensitive topics: None }\end{array}$ & $\begin{array}{l}\text { When decisions are allowed that are } \\
\text { inconsistent with guidelines: } 1 \\
\text { Major decision: } 1 \\
\text { Timing along the illness trajectory: None } \\
\text { Minor decision: None } \\
\text { Time to come to terms with diagnosis: None }\end{array}$ \\
\hline $\begin{array}{l}\text { Interactional } \\
\text { context factors }\end{array}$ & $\begin{array}{l}\text { Power (im) balance in the } \\
\text { patient-clinician relationship }\end{array}$ & $\begin{array}{l}\text { Presumptions about the patient role } \\
\text { Not having explicit 'permission' to participate in } \\
\text { SDM: } 6 \\
\text { Expectation of the clinician making the decisions: } \\
2 \\
\text { Desire to act as a 'good' patient (driven by fear of } \\
\text { consequences): } 1 \\
\text { Belief that clinicians do not want patients } \\
\text { involved: } 1\end{array}$ & $\begin{array}{l}\text { Presumptions about the patient role } \\
\text { Having explicit 'permission' to participate in } \\
\text { SDM: } 4 \\
\text { Perceived acceptability of asking the clinician } \\
\text { questions: None } \\
\text { Patients undervalue their expertise relative to } \\
\text { Clinicians } \\
\text { Recognizing there are two experts in the } \\
\text { medical encounter: } 5\end{array}$ \\
\hline
\end{tabular}

Perceived acceptability of asking the clinician questions: 1

Clinicians reinforces passivity by rewarding the behaviour: None

Patients undervalue their expertise relative to Clinicians

'Doctor knows best' and patients have 'inferior' knowledge: 3

Patients are not capable of understanding medical/technical information: 2

Interpersonal characteristics of the clinician

Trust

Preparation for an Perceived need for SDM encounter preparation

Expectation of SDM outcomes

Preparation for the SDM process options
Clinicians with poor interpersonal skills: 5

Authoritarian HCPs: 4

Clinician does not listen to patients concerns: 2 Perceptions that clinicians are already doing SDM: 1

Lack of individualized approach and not asked about preferences: 1

Clinician does not address patient directly: 1

Poor relationship with clinician: None

Trust in clinician: None

Lack of trust in clinician: 2

Patient does not want or need to participate in SDM: 4

Patient is not entitled to a choice: 1

Patient is not explicitly offered a choice or it is presented in a biased way: 1

'Doing nothing' is not an option: None Not knowing what to expect from the SDM consultation: None

Patient focus on treatment burden versus clinicians concerns about morbidity and mortality: 2

Not wanting responsibility for wrong decision: 1 Fear of accepting reality of diagnosis: None

Providing information about Insufficient information about condition, options and outcomes: 3

Clinician does not explain the options and outcomes: 2
Individualized approach where clinician seeks patient's preferences: 4

Clinicians with positive interpersonal skills: 2

Equal relationship: 1

Clinician listens to patients concerns: 1

Good relationship with clinician: None

Trust in clinician: 6

Lack of trust in clinician: None

Accepting responsibility to be involved in decision-making: 5

Setting an agenda: 1

Recognizing equipoise and uncertainty: 1

Sufficient information about condition, options and outcomes: 5 Clinician explains the options and outcomes: 
Table 2 Barriers and facilitators for SDM in older patients with MCCs (Continued)

\begin{tabular}{|c|c|c|c|}
\hline \multicolumn{2}{|l|}{ Factor } & \multirow{2}{*}{$\begin{array}{l}\text { Barriers (number of studies in which this } \\
\text { factor was identified as a barrier) } \\
\text { Clinician in repair-reflex mode (solutions without } \\
\text { listening to patient's preferences): } 1 \\
\text { No flexibility of clinicians when patients want } \\
\text { something different: } 1\end{array}$} & \multirow{2}{*}{$\begin{array}{l}\text { Facilitators (number of studies in which } \\
\text { this factor was identified as a facilitator) } \\
\text { Clinician knows patient's and informal } \\
\text { caregivers' priorities, goals and preferences: } 1\end{array}$} \\
\hline & & & \\
\hline & Terminology used by HCPs & Clinician uses medical terminology: 1 & Clinician uses simple terminology: 1 \\
\hline & Decision support & $\begin{array}{l}\text { Decision support from informal caregivers: } 4 \\
\text { Lack of written decision support: } 1 \\
\text { Purpose of decision support tool is unclear: None }\end{array}$ & $\begin{array}{l}\text { Decision support from others (e.g., family, } \\
\text { other professionals): } 15 \\
\text { Written decision support: None }\end{array}$ \\
\hline \multirow[t]{4}{*}{ Social context } & View of colleagues & $\begin{array}{l}\text { Disagreement between colleagues: } 3 \\
\text { Degree of contact between colleagues: } 1 \\
\text { Hierarchical structure of professionals: } 1\end{array}$ & \\
\hline & Culture of network & Social norms and values: None & Social norms and values: None \\
\hline & Collaboration & $\begin{array}{l}\text { Degree of cooperation and response between } \\
\text { colleagues: } 10\end{array}$ & $\begin{array}{l}\text { Degree of cooperation and response between } \\
\text { colleagues: } 6\end{array}$ \\
\hline & $\begin{array}{l}\text { Leadership and social } \\
\text { learning }\end{array}$ & $\begin{array}{l}\text { Lack of support from management (incentive, } \\
\text { feedback, role models): } 3\end{array}$ & $\begin{array}{l}\text { Support from management (incentive, } \\
\text { feedback, role models): None }\end{array}$ \\
\hline \multirow{3}{*}{$\begin{array}{l}\text { Organizational } \\
\text { context }\end{array}$} & Organizational characteristics & Complexity of the organization: 4 & Complexity of the organization: 1 \\
\hline & Capacities & No arrangements for continuous learning: 1 & Continuous learning opportunities: None \\
\hline & Organizational constraints & $\begin{array}{l}\text { Lack of resources (time): } 11 \\
\text { Lack of support services: } 2 \\
\text { Lack of resources (staff): } 4\end{array}$ & $\begin{array}{l}\text { Lack of resources (time): } 3 \\
\text { Lack of support services: None } \\
\text { Lack of resources (staff): None }\end{array}$ \\
\hline $\begin{array}{l}\text { Economic and } \\
\text { political context }\end{array}$ & Policy & $\begin{array}{l}\text { Unattractiveness of innovation by means of } \\
\text { financial arrangements: } 2\end{array}$ & $\begin{array}{l}\text { Attractiveness of innovation by means of } \\
\text { financial arrangements: } 1\end{array}$ \\
\hline Other & & 6 & None \\
\hline
\end{tabular}

${ }^{a}$ None' refers to the fact that no barrier or facilitator was found for this factor

overprotective or acting against professional advice (PP/IP/HP) [55]. Third, there can be conflicting views between informal caregivers and patients about treatment or care but also about the ability of the patient to communicate adequately with the health professional (PP/IP/HP) [51, 55, 59]. This might occur particularly in cases of cognitive decline. Finally, SDM can be complicated when there is not one but more than one informal caregiver involved, sometimes each with a different opinion (PP/IP/HP) [55].

\section{Perceived facilitators}

When patients had cognitive decline or were too ill, informal caregivers supported the decision-making process by providing information, asking questions and assisting in receiving and understanding information $(\mathrm{PP} / \mathrm{HP})[42$, $44,46,60,64,68]$. In addition, supportive informal caregivers ensured that patient preferences were recognized [51]. Furthermore, personal experiences of family and friends are important in balancing options (PP/IP/HP) $[50,56]$. Tailored information about conditions, options and outcomes was experienced as a facilitator to SDM (PP/HP) [44, 64]. Health professionals state that information about the patients' quality of life and functional status and knowledge about patient and informal caregivers' priorities, goals and preferences facilitates SDM (PP/IP/HP) [54].

\section{Social context \\ Perceived barriers}

Care for older patients with MCCs often involves many different types of health professionals often working in different health care settings. Poor or inefficient communication between them, leading to difficulty in prioritization and no one having the overview of a patient's case, was experienced as a barrier to SDM and to the need for integrated care in general (PP/IP/HP) $[47,55,60,61,63]$. Differences in vision, for example, medical focus versus focus on wellbeing, or conflicting ideas about patient involvement hamper SDM (PP/IP/HP) [53, 55, 67, 68].

\section{Perceived facilitators}

Conversely, good cooperation, communication and the use of the same vocabulary among the interdisciplinary team members facilitated SDM (HP) [61, 63, 67].

\section{Organizational context Perceived barriers}

Studies reporting organizational barriers were mostly situated in hospital settings $(n=8)$ or in primary care 
settings $(n=2)$. A high turnover in staff makes it difficult to get to know older patients and results in a lack of continuity of care and situations in which it is unclear who is responsible for the patient (HP) $[60,67,68]$. Lack of a good electronic patient record results in the patient having to frequently repeat explanations (PP/IP/HP) [54]. One study reported that patients sometimes felt urged to make room for new patients and that so-called 'shared decisions' about discharge were actually made solely by the professionals (PP) [46]. Discussing the personal preferences of older patients requires a relationship between the patient and clinician, and time is necessary to establish such a relationship. One study reported that when patients felt that the staff was stressed, they experienced less ability to participate in decision making (PP) [47].

\section{Perceived facilitators}

When the workflow is genuinely organized around the patient, this facilitates SDM (PP/IP/HP) [54].

\section{Economic and political context Perceived barriers}

When there is a system of payment for productivity, indicating that payment is only indicated when a medical treatment or intervention is chosen, this hampers the SDM process since choosing a treatment is then rewarded above watchful waiting ( $\mathrm{PP} / \mathrm{IP} / \mathrm{HP})$ [54]. Additionally, formal re-imbursement rules limit choices for patients (PP/HP) [52].

\section{Perceived facilitators}

On the other hand, a value-based payment system facilitates SDM, because the payment is then related to the outcomes relevant to the patient, which can range from comprehensive medical treatment to watchful waiting (PP/IP/HP) [54].

\section{Other perceived barriers}

Six barriers did not fit into the above framework. Patients mentioned having intense emotions, such as anger and frustration (PP) [42], and having a constantly changing medical condition, leading to difficulties in keeping up with information (PP) [44], as barriers for SDM.

\section{Differences in perspectives between patients, informal caregivers and health professionals}

Fig. 3 demonstrates how the main barriers and facilitators in this review were experienced from three different perspectives: patients, informal caregivers and health professionals. Almost all barriers and facilitators were reported from more than one perspective. For example, poor health is experienced as a barrier to SDM by patients, informal caregivers and health professionals.
The main barriers from a patient's perspective were found in predisposing factors $(n=24,20 \%)$ and interactional context factors $(n=23,19 \%)$. Informal caregivers experienced most barriers in predisposing factors ( $n=10,50 \%$ ), while health professionals reported mainly barriers in predisposing factors $(n=17,22 \%)$ and in the organizational context $(n=12,15 \%)$.

\section{Discussion}

We identified 28 studies papers reporting on perceived barriers and facilitators about SDM in older patients with MCCs. The main barriers for SDM as experienced by older patients with MCCs are ascribed to personal patient characteristics, such as poor health and/or cognitive or physical impairments. MCCs might complicate SDM in several ways: patients with MCCs experience less participation in SDM and health professionals experience difficulties with single diseased-based guidelines. Furthermore, patients and health professionals experience that differences in views on treatment burden versus morbidity and mortality complicates SDM. Additionally, with MCCs, there are often more health professionals involved, which may lead to conflicting views on treatment priorities, patient and caregiver involvement and no one coordinating and integrating patient care. Health professionals perceive poor interpersonal skills as a barrier to SDM as well as organizational barriers, such as pressure for time and high turnover of patients. Financial incentives, such as payments for productivity, are experienced as counterproductive to SDM, when 'doing nothing' is also an important option to discuss. However, older patients with MCCs perceive that SDM is facilitated when patients share information about personal values, priorities and preferences, and information about quality of life and functional status. Decision support by informal caregivers is perceived as a facilitator to SDM, although informal caregivers can also complicate the SDM process, for example, when an informal caregiver has different views on treatment or about the patient's capability to be involved. The main experienced facilitator for SDM is an individualized approach in which health professionals probe and prioritise patient preferences. Coordination of care when multiple health professionals are involved seems important.

Most of the main perceived barriers and facilitators for SDM were reported from more than one perspective. There was great overlap between patients and health professionals in what they perceived as helping or hindering SDM. Commonly experienced, frequently reported barriers included patient characteristics (poor health, cognitive impairments), poor communication techniques by health professionals and organizational constraints (e.g., time pressure). Commonly experienced facilitators were acknowledgement of the complex 


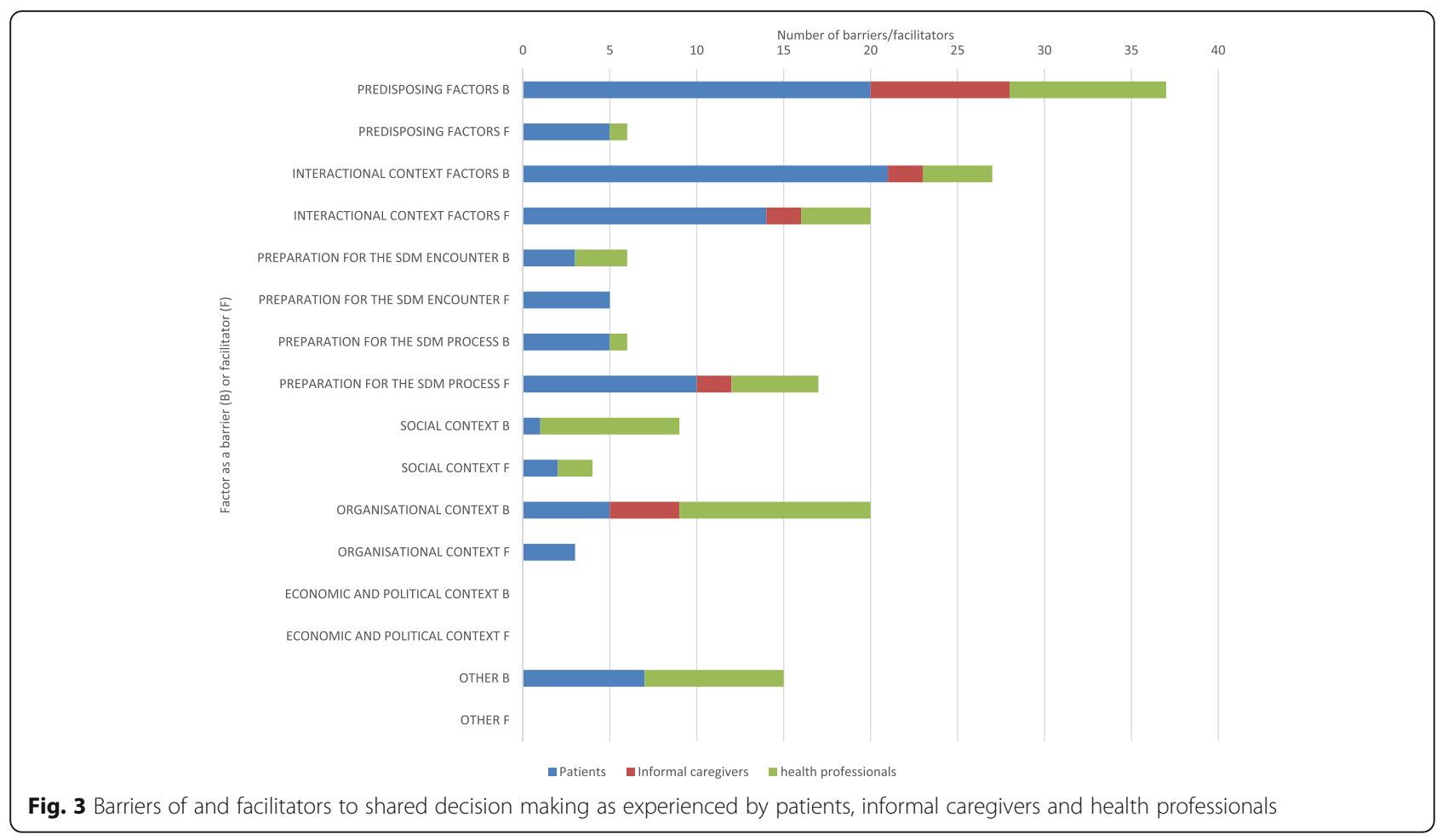

conditions of patients by health professionals and the effect of this factor on participation in SDM.

These findings should be considered in relation to other reviews about the implementation of SDM. We found that poor health and cognitive impairment in older patients are perceived barriers to participation in SDM, whereas other reviews do not reveal these factors as important barriers. This observation suggests that the presence of MCCs in old age requires more effort from health professionals to engage patients in SDM. The review of Joseph-Williams (2014) emphasizes the importance of knowledge to patients when participating in SDM; patients often feel insecure about their own medical knowledge and undervalue their knowledge about their personal situation and experiences [19]. The current review confirms that patients often underestimate their own expertise [70] but, in contrast, reveals that due to their MCCs, they feel more experienced in using health care facility systems than those with single health conditions $[41,46]$ and perceive that because of the chronic aspect of their conditions, they have greater knowledge about their particular condition and preferences [44]. Feeling no permission to participate in SDM is also mentioned in the review by Joseph-Williams and is consistent with our findings. A review of the key components of SDM models found that only about one third of SDM models includes 'discussing the preferred roles of patients' and 'communicating that the patients' opinion is important' [71]. Elwyn et al. (2017) transformed the first step of their SDM model 'Choice talk' to 'Team talk', emphasizing the importance of explaining the intention to collaborate and support deliberation [11]. During the development of the 'Dynamic model for SDM in frail older patients' [72], patients stressed the importance of being engaged in the dialogue [72].

Consistent with previous research, we found that professionals perceive a lack of agreement on the SDM process or SDM aids [20, 73]. In our study, this is ascribed to the involvement of multiple professionals in the case of patients with MCCs. Although the aspect of time is also described in existing reviews about the implementation of SDM [19-21, 73], the findings in this review stress that health professionals experience that more time is needed to establish a relationship with older patients.

This review also addressed the informal caregivers' perspective on SDM. Echoing previous research, we found that decision support from informal caregivers is experienced as a considerable facilitator to SDM [3537], however, there are several ways in which decision support from informal caregivers may also pose a burden on SDM [51, 55, 59].

Our findings should also be interpreted in the broader context of SDM developments. This study highlights that for older adults with MCCs an individualized approach is needed, taking into account the personal experience of patients that live with chronic conditions facilitate SDM. These personal experiences may direct 
the discussion about patients' personal preferred health outcomes. This in line with the 'Action Steps for decision making for older adults with MCCss, according to the MCCs guiding principles, that emphasizes to start with identifying and communicating patients' preferences and priorities [74]. Although older adults vary in whether they want and are able to participate in SDM, considering preferences is relevant for all patients [41, 47, 60, 74]. Tinetti (2019) found that working according to patients' priorities led to less treatment burden and less unwanted healthcare [75]. They also reported that initial fear among physicians that patients would formulate unrealistic goals was unjustified; if patient were guided through the SDM process, they formulated personal and realistic goals. This was confirmed by the study of Feder (2019) who also found that discussing personal goals led to a better relationship with physicians [76].

We conducted a broad and systematic search; however, although we searched for studies about SDM in other health disciplines, most studies targeted clinicians. Furthermore, using an existing taxonomy has advantages and disadvantages. This taxonomy used in this study to structure barriers and facilitators was developed and used in previous reviews, thus making a comparison of the results possible. However, we found additional barriers and facilitators; those barriers were directly related to the characteristic features of SDM for older patients with MCCs, which was not a target population during the original development of the taxonomy. Barriers that were added to the taxonomy were 'Disease-based decision models (guidelines)', 'Burden of treatment regimen', 'Patient focus on treatment burden versus clinicians concerns about morbidity and mortality' and 'Decision support from informal caregivers'. As facilitators were added: When decisions are allowed that are inconsistent with guidelines' and 'setting an agenda'.

\section{Conclusions}

Although poor health is experienced as a barrier to participate in SDM, the personal experience of living with MCCs is perceived as valuable to SDM. Patients feel that an explicit invitation to participate in SDM is important. Informal caregivers would like to be respected as full partners in the SDM process; however, more research on their perspective is required. Health professionals expressed they need a supporting organizational context and good communication skills to work out an individualized approach for care. Finally, health professionals consider a value-based payment system as a facilitator to SDM unlike a payment-for-productivity system.

\section{Supplementary Information}

The online version contains supplementary material available at https://doi. org/10.1186/s12877-021-02050-y.
Additional file 1: Supplementary Table S1. Medline via Ovid search strategy

Additional file 2: Supplementary Table S2. Taxonomy of barriers and facilitators

Additional file 3: Supplementary Table S3. Quality assessment of included studies

\section{Abbreviations}

SDM: Shared decision making; MCCs: Multiple chronic conditions; PRIS MA: Preferred reporting items for systematic reviews and meta-analysis; SQAC: Standard quality assessment criteria for evaluating primary research papers from a variety of fields

Acknowledgements

Not applicable.

Authors' contributions

Study concept and design: RP, MS, NT, WSR. Acquisition of data: RP, NT, FE. Analysis and interpretation of data: RP, NT, MS. Preparation and critical revision of the manuscript: RP, MS, WSR, NT, BB, MM, JW. All authors have read and approved the manuscript.

\section{Funding}

This work was supported by ZonMw [grant number 520002002]. Sponsor's role: the funding agency had no role in the study design, methods, and subject requirement; in the collection, analysis and interpretation of data; in the writing of the report; or in the decision to submit the article for publication.

Availability of data and materials

The dataset(s) supporting the conclusions of this article are included within the article (and its additional files).

Ethics approval and consent to participate

Not applicable.

Consent for publication

Not applicable.

\section{Competing interests}

The authors declare that they have no competing interests.

\section{Author details}

'Vilans, Centre of Expertise for Long-term Care, PO Box 8228, Utrecht, RE 3503, the Netherlands. ${ }^{2}$ Department of Internal Medicine, Section of Geriatric Medicine, Amsterdam University Medical Center, University of Amsterdam, Amsterdam, the Netherlands. ${ }^{3}$ ACHIEVE, Centre of Applied Research, Faculty of Health, Amsterdam University of Applied Sciences, Amsterdam, the Netherlands. ${ }^{4}$ Medical Library, Amsterdam University Medical Centre,

University of Amsterdam, Amsterdam, the Netherlands. ${ }^{5}$ Amsterdam School of Communication Research/ASCoR, University of Amsterdam, Amsterdam, the Netherlands. 'University of Tilburg/TIAS School for Business and Society, Tilburg, the Netherlands. 'Department of Cardiology, Academic Medical Centre, University of Amsterdam, Amsterdam, the Netherlands.

Received: 26 March 2020 Accepted: 25 January 2021

Published online: 06 February 2021

References

1. Gijsen R, Hoeymans N, Schellevis FG, Ruwaard D, Satariano WA, van den Bos GA. Causes and consequences of comorbidity: a review. J Clin Epidemiol. 2001;54(7):661-74.

2. Barnett K, Mercer SW, Norbury M, Watt G, Wyke S, Guthrie B. Epidemiology of multimorbidity and implications for health care, research, and medical education: a cross-sectional study. Lancet. 2012;380(9836):37-43.

3. Vetrano DL, Foebel AD, Marengoni A, Brandi V, Collamati A, Heckman GA, Hirdes J, Bernabei R, Onder G. Chronic diseases and geriatric syndromes: the different weight of comorbidity. Eur J Intern Med. 2016;27:62-7.

4. Salisbury C. Multimorbidity: redesigning health care for people who use it Lancet. 2012;380(9836):7-9. 
5. Vetrano DL, Calderon-Larranaga A, Marengoni A, Onder G, Bauer JM, Cesari $M$, Ferrucci L, Fratiglioni L. An international perspective on chronic multimorbidity: approaching the elephant in the room. J Gerontol A Biol Sci Med Sci. 2018;73(10):1350-6. https://doi.org/10.1093/gerona/glx178.

6. Marengoni A, Angleman S, Melis R, Mangialasche F, Karp A, Garmen A, Meinow B, Fratiglioni L. Aging with multimorbidity: a systematic review of the literature. Ageing Res Rev. 2011;10(4):430-9.

7. Rizzuto D, Melis RJF, Angleman S, Qiu C, Marengoni A. Effect of chronic diseases and multimorbidity on survival and functioning in elderly adults. J Am Geriatr Soc. 2017;65(5):1056-60.

8. Prados-Torres A, Calderon-Larranaga A, Hancco-Saavedra J, Poblador-Plou B, van den Akker M. Multimorbidity patterns: a systematic review. J Clin Epidemiol. 2014;67(3):254-66.

9. Gu J, Chao J, Chen W, Xu H, Zhang R, He T, Deng L. Multimorbidity and health-related quality of life among the community-dwelling elderly: a longitudinal study. Arch Gerontol Geriatr. 2017;74:133-40.

10. Vermunt NP, Harmsen M, Elwyn G, Westert GP, Burgers JS, Olde Rikkert MG, Faber MJ. A three-goal model for patients with multimorbidity: a qualitative approach. Health Expect. 2018;21(2):528-38.

11. Elwyn G, Durand MA, Song J, Aarts J, Barr PJ, Berger Z, Cochran N, Frosch D, Galasinski D, Gulbrandsen P, et al. A three-talk model for shared decision making: multistage consultation process. BMJ (Clinical research ed). 2017; 359:j4891.

12. van Weert JC, van Munster BC, Sanders R, Spijker R, Hooft L, Jansen J. Decision aids to help older people make health decisions: a systematic review and meta-analysis. BMC Med Inform Decis Making. 2016;16:45.

13. Pieterse $A H$, Finset $A$. Shared decision making-much studied, much still unknown. Patient Educ Couns. 2019;102(11):1946-8.

14. Shay LA, Lafata JE. Where is the evidence? A systematic review of shared decision making and patient outcomes. Med Decis Mak. 2015;35(1):114-31.

15. Stacey D, Legare F, Lewis K, Barry MJ, Bennett CL, Eden KB, Holmes-Rovner M, Llewellyn-Thomas H, Lyddiatt A, Thomson R, et al. Decision aids for people facing health treatment or screening decisions. Cochrane Database Syst Rev. 2017:4:Cd001431.

16. Kashaf MS, McGill E. Does shared decision making in Cancer treatment improve quality of life? A systematic literature review. Med Decis Mak. 2015; 35(8):1037-48.

17. Saheb Kashaf M, McGill ET, Berger ZD. Shared decision-making and outcomes in type 2 diabetes: a systematic review and meta-analysis. Patient Educ Couns. 2017:100(12):2159-71.

18. Godolphin W. Shared decision-making. Healthc Q. 2009;12 Spec No Patient: e186-90.

19. Joseph-Williams N, Elwyn G, Edwards A. Knowledge is not power for patients: a systematic review and thematic synthesis of patient-reported barriers and facilitators to shared decision making. Patient Educ Couns. 2014;94(3):291-309.

20. Elwyn G, Scholl I, Tietbohl C, Mann M, Edwards AG, Clay C, Legare F, van der Weijden T, Lewis CL, Wexler RM, et al. "Many miles to go ...": a systematic review of the implementation of patient decision support interventions into routine clinical practice. BMC Med Inform Decis Making. 2013;13(Suppl 2):S14.

21. Gravel K, Legare F, Graham ID. Barriers and facilitators to implementing shared decision-making in clinical practice: a systematic review of health professionals' perceptions. Implement Sci. 2006;1:16.

22. Daly RL, Bunn F, Goodman C. Shared decision-making for people living with dementia in extended care settings: a systematic review. BMJ Open. 2018; 8(6):e018977.

23. Jansen J, Naganathan V, Carter SM, McLachlan AJ, Nickel B, Irwig L, Bonner C, Doust J, Colvin J, Heaney A, et al. Too much medicine in older people? Deprescribing through shared decision making. BMJ (Clinical research ed). 2016;353:i2893.

24. Bryant $\mathrm{C}$, Jackson $\mathrm{H}$, Ames $\mathrm{D}$. The prevalence of anxiety in older adults: methodological issues and a review of the literature. J Affect Disord. 2008; 109(3):233-50

25. DiMatteo MR, Lepper HS, Croghan TW. Depression is a risk factor for noncompliance with medical treatment: meta-analysis of the effects of anxiety and depression on patient adherence. Arch Intern Med. 2000; 160(14):2101-7.

26. Tang VL, Covinsky K. Frailty and surgical decision making. Ann Intern Med. 2016;165(9):669-70.
27. MacLeod S, Musich S, Gulyas S, Cheng Y, Tkatch R, Cempellin D, Bhattarai GR, Hawkins K, Yeh CS. The impact of inadequate health literacy on patient satisfaction, healthcare utilization, and expenditures among older adults. Geriatr Nurs (New York, NY). 2017;38(4):334-41.

28. Chesser AK, Keene Woods N, Smothers K, Rogers N. Health literacy and older adults: a systematic review. Gerontol Geriatr Med. 2016;2: 2333721416630492

29. Frosch DL, Kaplan RM. Shared decision making in clinical medicine: past research and future directions. Am J Prev Med. 1999;17(4):285-94.

30. Geboers B, Brainard JS, Loke YK, Jansen CJ, Salter C, Reijneveld SA, de Winter AF. The association of health literacy with adherence in older adults, and its role in interventions: a systematic meta-review. BMC Public Health. 2015;15:903.

31. Berkman ND, Sheridan SL, Donahue KE, Halpern DJ, Crotty K. Low health literacy and health outcomes: an updated systematic review. Ann Intern Med. 2011;155(2):97-107.

32. Aubertin-Leheudre M, Woods AJ, Anton S, Cohen R, Pahor M. Frailty clinical phenotype: a physical and cognitive point of view. Nestle Nutr Inst workshop Ser. 2015;83:55-63.

33. Pel-Littel RE, Buurman BM, van de Pol MH, Yilmaz NG, Tulner LR, Minkman MM, WJM SOR, Elwyn G, JCM $\vee$ W. Measuring triadic decision making in older patients with multiple chronic conditions: observer OPTION (MCCS). Patient Educ Couns. 2019;102(11):1969-76.

34. Institute of Medicine Committee on the Future Health Care Workforce for Older A: Patients and informal caregivers, Chapter 6. Retooling for an Aging America: Building the Health Care Workforce. Washington (DC): National Academies Press (US) Copyright 2008 by the National Academy of Sciences. All rights reserved; 2008.

35. Clayman ML, Roter D, Wissow LS, Bandeen-Roche K. Autonomy-related behaviors of patient companions and their effect on decision-making activity in geriatric primary care visits. Soc Sci Med. 2005;60(7):1583-91.

36. Wolff $J$, Roter DL. Hidden in plain sight: medical visit companions as a resource for vulnerable older adults. Arch Intern Med. 2008;168(13):1409-15.

37. Laidsaar-Powell RC, Butow PN, Bu S, Charles C, Gafni A, Lam WW, Jansen J, McCaffery KJ, Shepherd HL, Tattersall MH, et al. Physician-patientcompanion communication and decision-making: a systematic review of triadic medical consultations. Patient Educ Couns. 2013;91(1):3-13.

38. Grol $R$, Wensing M. What drives change? Barriers to and incentives for achieving evidence-based practice. Med J Aust. 2004;180(6 Suppl):S57-60.

39. Shamseer L, Moher D, Clarke M, Ghersi D, Liberati A, Petticrew M, Shekelle P, Stewart LA. Preferred reporting items for systematic review and metaanalysis protocols (PRISMA-P) 2015: elaboration and explanation. BMJ (Clinical research ed). 2015;350:97647.

40. Kmet L, Lee R, Cook L. Standard quality assessment criteria for evaluating primary research papers from a variety of fields. In: HTA Initiative \#13 Edmonton; Alberta Heritage Foundation for Medical Research (AHFMR); 2004

41. Funk LM. Who wants to be involved? Decision-making preferences among residents of long-term care facilities. Can J Aging. 2004;23(1):47-58.

42. Gauthier DM. Decision making near the end of life. J Hosp Palliat Nurs. 2005;7(2):82-90.

43. Naik AD, Street RL Jr, Castillo D, Abraham NS. Health literacy and decision making styles for complex antithrombotic therapy among older multimorbid adults. Patient Educ Couns. 2011;85(3):499-504.

44. Belcher VN, Fried TR, Agostini JV, Tinetti ME. Views of older adults on patient participation in medication-related decision making. J Gen Intern Med. 2006;21(4):298-303.

45. Chi WC, Wolff J, Greer R, Dy S. Multimorbidity and decision-making preferences among older adults. Ann Fam Med. 2017;15(6):546-51.

46. Dyrstad DN, Laugaland KA, Storm M. An observational study of older patients' participation in hospital admission and discharge--exploring patient and next of kin perspectives. J Clin Nurs. 2015;24(11-12):1693-706.

47. Ekdahl AW, Andersson L, Friedrichsen M. "they do what they think is the best for me." frail elderly patients' preferences for participation in their care during hospitalization. Patient Educ Couns. 2010;80(2):233-40.

48. Ekdahl AW, Andersson L, Wirehn AB, Friedrichsen M. Are elderly people with co-morbidities involved adequately in medical decision making when hospitalised? A cross-sectional survey. BMC Geriatr. 2011;11:46.

49. Erickson GP. Ethical dilemmas in home care of chronically ill elderly persons. Home Healthc Nurse. 1989;6(6):19-23. 
50. Petrillo LA, McMahan RD, Tang V, Dohan D, Sudore RL. Older adult and surrogate perspectives on serious, difficult, and important medical decisions. J Am Geriatr Soc. 2018;66(8):1515-23.

51. Riffin C, Van Ness PH, lannone L, Fried T. Patient and caregiver perspectives on managing multiple health conditions. J Am Geriatr Soc. 2018;66(10): 1992-7.

52. Kiselev J, Mellenthin E, Steinhagen-Thiessen E. Attitudes of health professionals and patients in a geriatric hospital towards patient involvement. Int J Integr Care (IJIC). 2017;17:1-2.

53. Rose A, Soundy A, Rosewilliam S. Shared decision-making within goalsetting in rehabilitation: a mixed-methods study. Clin Rehabil. 2019;33(3): 564-574. https://doi.org/10.1177/0269215518815251.

54. Ferris R, Blaum C, Kiwak E, Austin J, Esterson J, Harkless G, Oftedahl G, Parchman M, Van Ness PH, Tinetti ME. Perspectives of patients, clinicians, and health system leaders on changes needed to improve the health care and outcomes of older adults with multiple chronic conditions. J Aging Health. 2018;30(5):778-99.

55. Doekhie KD, Strating MMH, Buljac-Samardzic M, van de Bovenkamp HM, Paauwe J. The different perspectives of patients, informal caregivers and professionals on patient involvement in primary care teams. A qualitative study. Health Expect. 2018;21(6):1171-82.

56. Puts MT, Sattar S, McWatters K, Lee K, Kulik M, MacDonald ME, Jang R, Amir E, Krzyzanowska MK, Leighl N, et al. Chemotherapy treatment decisionmaking experiences of older adults with cancer, their family members, oncologists and family physicians: a mixed methods study. Support Care Cancer. 2017;25(3):879-86.

57. Bragstad LK, Kirkevold M, Foss C. The indispensable intermediaries: a qualitative study of informal caregivers' struggle to achieve influence at and after hospital discharge. BMC Health Serv Res. 2014;14:331.

58. Menne $\mathrm{HL}$, Whitlatch CJ. Decision-making involvement of individuals with dementia. The Gerontologist. 2007;47(6):810-9.

59. Peacock S, Sethi B, Williams A, Duggleby W, Bayly M, Swindle J, Ploeg J, Markle-Reid M. Older adult spouses with multiple chronic conditions: challenges, rewards, and coping strategies. Can J Aging. 2017;36(2):209-22.

60. Ekdahl AW, Hellstrom I, Andersson L, Friedrichsen M. Too complex and time-consuming to fit in! Physicians' experiences of elderly patients and their participation in medical decision making: a grounded theory study. BMJ Open. 2012;2(3):e001063. https://doi.org/10.1136/bmjopen-2012001063.

61. Fried TR, Tinetti ME, lannone L. Primary care clinicians' experiences with treatment decision making for older persons with multiple conditions. Arch Intern Med. 2011;171(1):75-80.

62. Blaum CS, Rosen J, Naik AD, Smith CD, Dindo L, Vo LH, ez-Bigos K, Esterson J, Geda M, et al. Feasibility of implementing patient priorities Care for Older Adults with multiple chronic conditions. J Am Geriatr Soc. 2018;66(10):2009-16.

63. Gopalraj RK, Grooms L, Setters BK, Kaundar A, Furman CD. Decision-making in older adults with serious illness: barriers to the goals of care discussion. Aging Health. 2012:8(4):367-76

64. Milte CM, Ratcliffe J, Davies O, Whitehead C, Masters S, Crotty M. Family meetings for older adults in intermediate care settings: the impact of patient cognitive impairment and other characteristics on shared decision making. Health Expect. 2015;18(5):1030-40.

65. Schuling J, Gebben H, Veehof LJ, Haaijer-Ruskamp FM. Deprescribing medication in very elderly patients with multimorbidity: the view of Dutch GPs. A qualitative study. BMC Fam Pract. 2012;13:56.

66. Molinari V, McCullough LB, Coverdale JH, Workman R. Principles and practice of geriatric assent. Aging Ment Health. 2006;10(1):48-54.

67. Legare F, Stacey D, Briere N, Fraser K, Desroches S, Dumont S, Sales A, Puma C, Aube D. Healthcare providers' intentions to engage in an interprofessional approach to shared decision-making in home care programs: a mixed methods study. J Interprof Care. 2013;27(3):214-22.

68. Lindhardt T, Hallberg IR, Poulsen I. Nurses' experience of collaboration with relatives of frail elderly patients in acute hospital wards: a qualitative study. Int J Nurs Stud. 2008;45(5):668-81.

69. Fried LP, Tangen CM, Walston J, Newman AB, Hirsch C, Gottdiener J, Seeman T, Tracy R, Kop WJ, Burke G, et al. Frailty in older adults: evidence for a phenotype. J Gerontol A Biol Sci Med Sci. 2001;56(3):M146-56.

70. Joseph-Williams N, Edwards A, Elwyn G. Power imbalance prevents shared decision making. BMJ (Clinical research ed). 2014;348:93178.

71. Bomhof-Roordink H, Gartner FR. Key components of shared decision making models: a systematic review. BMJ Open. 2019;9(12):e031763.
72. van de Pol MH, Fluit CR, Lagro J, Slaats YH, Olde Rikkert MG, Lagro-Janssen AL. Expert and patient consensus on a dynamic model for shared decisionmaking in frail older patients. Patient Educ Couns. 2016;99(6):1069-77.

73. Legare F, Ratte S, Gravel K, Graham ID. Barriers and facilitators to implementing shared decision-making in clinical practice: update of a systematic review of health professionals' perceptions. Patient Educ Couns. 2008;73(3):526-35.

74. Boyd C, Smith CD, Masoudi FA, Blaum CS, Dodson JA, Green AR, Kelley A, Matlock D, Ouellet J, Rich MW, et al. Decision making for older adults with multiple chronic conditions: executive summary for the American Geriatrics Society guiding principles on the Care of Older Adults with Multimorbidity. J Am Geriatr Soc. 2019;67(4):665-73

75. Tinetti ME, Naik AD, Dindo L, Costello DM, Esterson J, Geda M, Rosen J, Hernandez-Bigos K, Smith CD, Ouellet GM, Kang G, Lee Y, Blaum C. Association of Patient Priorities-Aligned Decision-Making with Patient Outcomes and Ambulatory Health Care Burden among Older Adults with Multiple Chronic Conditions: a nonrandomized clinical trial. JAMA Intern Med. 2019;179(12):1688-97. https://doi.org/10.1001/jamainternmed.2019. 4235.

76. Feder SL, Kiwak E, Costello D, Dindo L, Hernandez-Bigos K, Vo L, Geda M, Blaum C, Tinetti ME, Naik AD. Perspectives of patients in identifying their values-based health priorities. J Am Geriatr Soc. 2019:67(7):1379-85.

\section{Publisher's Note}

Springer Nature remains neutral with regard to jurisdictional claims in published maps and institutional affiliations.
Ready to submit your research? Choose BMC and benefit from:

- fast, convenient online submission

- thorough peer review by experienced researchers in your field

- rapid publication on acceptance

- support for research data, including large and complex data types

- gold Open Access which fosters wider collaboration and increased citations

- maximum visibility for your research: over $100 \mathrm{M}$ website views per year

At $\mathrm{BMC}$, research is always in progress.

Learn more biomedcentral.com/submissions 